УДК 001.3; 001.82; 16; 316.628

\title{
НОММАGЕ ДМИТРИЮ ИВАНОВИЧУ ТРУБЕЦКОВУ, ИЛИ УЧЁНЫЙ И ВРЕМЕНА: ТИПОЛОГИЯ ОТНОШЕНИЙ
}

\author{
Б. Н. Пойзнер \\ Национальный исследовательский Томский государственный университет \\ Россия, 634050 Томск, пр. Ленина, 36 \\ E-mail: pznr@mail.tsu.ru \\ Поступила в редакцию 24.04.2018
}

\begin{abstract}
Цель. Целью работы является модель отношений учёного с эволюционирующей социальной системой. Модель описывает ключевые компоненты творческой деятельности, особенности социокультурной ситуации и фракторы, способные повлиять на творческую продуктивность. Метод. Метод исследования объединяет принципы описания целеустремлённой системы деятельности (В.И. Корогодин, 1991), шкалу творческих субъектов (Э.А. Соснин, 2011), неологизмы «креатема», «соисторичность», «хронема» (М.Н. Эпштейн, 2017). Результаты. Введено рабочее понятие «творческий контекст», раскрывающее условия, в которых действует учёный. Контексты отличаются степенью мотивации (демотивации) учёного. Предложен принцип упорядочения творческих контекстов. Составлена таблица из 16 контекстов, которая может служить эвристикой начинающему исследователю. Содержание таблицы позволяет исследователю: рефлексировать компоненты своей деятельности, оценивать творческий уровень; диагностировать текущую стадию эволюции творческого коллектива; соотносить уровни своего творчества с этой стадией; соотносить свои творческие притязания с этапом эволюции социальной системы.
\end{abstract} Обсуждение. Обоснованы допущения, при которых построена таблица контекстов, даны комментарии к ней. Отдельные творческие контексты из таблицы могут быть верифицированы на историко-научных сюжетах в книгах Д.И. Трубецкова, С.Э. Шноля, М. Перутца. В порядке дискуссии выдвинуты понятия: «дизергия» (антоним синергии) и «недостоверное настоящее» (характеристика стадии деградации социальной системы). Анализируется тезис: степень мотивации (демотивации) учёного зависит от меры синергии (дизергии) между уровнем его творчества и стадией жизненного цикла социальной системы.

Ключевые слова: структура творческой деятельности и её рефлексия, мотивация и демотивация творчества, жизненный цикл социальной системы, постсоветский проект, Новейшее средневековье, Д.И. Трубецков.

DOI: 10.18500/0869-6632-2018-26-3-127-153

Образец цитирования: Пойзнер Б.Н. Hommage Дмитрию Ивановичу Трубецкову, или Учёный и времена: Типология отношений // Известия вузов. Прикладная нелинейная динамика. 2018. T. 26, No 3. C. 127-153. DOI: 10.18500/0869-6632-2018-26-3-127-153 


\title{
HOMMAGE DMITRY IVANOVICH TRUBETSKOV, OR SCIENTIST AND TIMES: TYPOLOGY OF RELATIONS
}

\author{
B. N. Poizner \\ National Research Tomsk State University \\ 36, Lenin Avenue, 634050 Tomsk, Russia \\ E-mail: pznr@mail.tsu.ru \\ Received 24.04.2018
}

\begin{abstract}
Aim of the work is the model of relations between the scientist and the evolving social system. The model describes the key components of creative activity, the features of the sociocultural situation and the factors that can affect creative productivity. Method of the study combines principles of the description of a purposeful activity system by V. I. Korogodin, scale of creative subjects by E. A. Sosnin, as well as introduced by M.N. Epstein the concepts of createme, cohistoricity, chroneme, etc. Results. The working concept "creative context», revealing the conditions in which the scientist operates, is introduced. Contexts differ in the motivation (or demotivation) degree of the scientist. The principle of creative contexts ordering is proposed. A table containing 16 contexts of creativity is constructed (under the assumptions made). The table and comments to it can serve as a heuristic to a novice researcher. In particular, he is capable of: reflecting the components of the purposeful activity system; evaluating the creative level; diagnose the current stage of the evolution of the creative team; to correlate the levels of his creativity with this stage; to correlate his creative claims with the evolution stage of the social system. Discussion. The assumptions under which the table of contexts is constructed are substantiated, and comments to it are given. Some creative contexts from the table can be verified on historical and scientific subjects in the books of D. I. Trubetskov, S. E. Shnol, M. Perutz. As a matter for discussions concepts «dysergy» (the antonym of synergy) and the «false present» or the «unreliable present» (characteristic of the stage of degradation of the social system) are proposed. The thesis is analyzed: the degree of motivation (or demotivation) of a scientist depends on the measure of synergy (or dysergy) between the level of his creativity and the stage of the life cycle of the social system.
\end{abstract}

Key words: structure of creative activity and its reflection, motivation and demotivation of creativity, life cycle of the social system, post-Soviet project, The Newest Middle Ages, D.I. Trubetskov.

DOI: 10.18500/0869-6632-2018-26-3-127-153

Reference: Poizner B.N. Hommage Dmitry Ivanovich Trubetskov, or Scientist and times: Typology of relations. Izvestiya VUZ, Applied Nonlinear Dynamics, 2018, vol. 26, no. 3, pp. 127-153. DOI: 10.18500/0869-6632-2018-26-3-127-153 